\title{
高張力鋼を使用した船殼部材の 疲労強度に関する考察
}

\author{
正員 的 場 正 明* 正員 井 上 克 明* \\ Fatigue Strength of Hull in Use of High Tensile Steel \\ by Masaaki Matoba, Member Katsuaki Inoue, Member
}

\begin{abstract}
Summary
To improve the effectiveness in ship performance, more and more high tensile steel has come to be employed than hitherto.

One of the problems to be addressed when using the high tensile steel for the ship hull is that of fatigue strength. For with the high tensile steel, compared with mild steel, its fatigue strength does not improve so much as its tensile strength when used in the ship hull.

The authors studied the high tensile steel $K$ factor based on relevant literatures and, to increase the fatigue strength of high tensile steel structure, explored the possibility of fabrication process improvement by the TIG dressing, as well as of structural improvement by modifying, for example, the vertical frame bottom end and the slot in the transverse ring. In this connection, test was conducted, which was a basic model test using a simple specimen fabricated by fillet welding two adjoining attachment to a flat plate.

The studies showed that although the high tensile steel structure would exhibit almost no appreciable improvement in fatigue strength at the welded joints of high stress concentration as compared with the mild steel structure, this shortcoming could be dealt with by slightly modifying the detail structure. It was also found that the TIG dressing would not raise but reduce the structural strength when the fillet welded joints were located very close to each other.
\end{abstract}

\section{1 概 要}

新造船における性能向上のために高張力鋼の採用比率 が高まっている。

船殼部材に高張力鋼を使用する際に注意すべき点の一 つに疲労強度がある。すなわち, 高張力鋼は軟鋼と比べ て, 引張強度の向上度合ほど疲労強度は向上しない。

本研究では，文献調查により高張力鋼係数に関し考察 を行い,さらに高張力鋼の疲労強度向上対策として, TIG ドレスによる施工面での改良と，ホールドフレー ム下端とスロットを例に詳細構造の改良について考察し た。

この際，基礎モデルとして近接した 2 個の隅肉溶接さ れた付加物を有する継手のテストを行い考察の基礎デー タとした。

研究の結果, 高張力鋼は応力集中の大きな継手では, 軟鋼と比べ疲労強度向上はほとんど認められないが, 詳 * 三菱重工業(株)長崎研究所
細構造の若干の改良により対策しうることを確認した。 また TIG ドレスによる疲労強度向上対策は溶接ビード が近接した場合, 逆に強度が低下することを明らかにし た。

\section{2 各種ルールにおける高張力鋼係数}

各種の機種を対象に溶接継手の疲労許容応力（規格） が示されているが, 抗張力 $41 \mathrm{~kg} / \mathrm{mm}^{2} \sim 55 \mathrm{~kg} / \mathrm{mm}^{2}$ 程 度で注許容応力差をつけていない規格が多い。その理 由は強度特に疲労限強度に有意差が認められないことで ある。許容応力に差をつけていない規格としてたとえ代 下記がある。

ASME Sec III (1975)：原子力, ボイラーおよび圧力 容器 (米)

AWS (1976)：橋梁等一般鋼構造物 (米)

本四連絡橋（昭和 49 年）：土木学会

BS 153 (1972): 橋梁 (英)

抗張力 $55 \mathrm{~kg} / \mathrm{mm}^{2}$ クラスの鋼材の継手の疲労強度は 
Table 1 GL's high tensile steel strength ratio on fatigue view

\begin{tabular}{|c|c|c|c|c|c|c|}
\hline & \multirow{2}{*}{ Notch Group } & \multirow{2}{*}{ c } & \multicolumn{2}{|c|}{$\begin{array}{l}\text { Strength Ratio } \\
\text { to Mild Steel }\end{array}$} & \multicolumn{2}{|c|}{ K Factor } \\
\hline & & & $32 \mathrm{k}$ Class & $36 \mathrm{k}$ Class & $32 \mathrm{k}$ Class & $36 \mathrm{k}$ Class \\
\hline$k_{0}$ & $\begin{array}{l}\text { Base Metal, } \\
\text { Flashed Long Weld }\end{array}$ & 1.0 & 1.28 & 1.4 & 0.78 & 0.714 \\
\hline$K_{1}$ & $\begin{array}{l}\text { Trans Butt weld } \\
\text { Cont. Fillet keld } \\
\text { Special Class }\end{array}$ & 0.8 & 1.18 & 1.256 & 0.847 & 0.796 \\
\hline & $\begin{array}{l}\text { Light Tapered Butt Weld } \\
\text { Usual Cont. Fillet Weld }\end{array}$ & 0.6 & 1.10 & 1.144 & 0.91 & 0.874 \\
\hline & $\begin{array}{l}\text { Roud Welded } \\
\text { Atachment }\end{array}$ & 0.4 & 1.045 & 1.064 & 0.957 & 0.94 \\
\hline$K_{4}$ & $\begin{array}{l}\text { Round Welded } \\
\text { Atachment Notsoft }\end{array}$ & 0.2 & 1.011 & 1.016 & 0.989 & 0.984 \\
\hline
\end{tabular}

SR 193，SR200-11 の他文献2) で収集さ れている。その結果最近の新制御圧延鋼 ( TMCP鋼) は通常高張力鋼と疲労強度上 差異がないことも判明している。本研究 では, 各継手での累積被害度を算出する 目的で，軟鋼および高張力鋼の黒皮付母 材, 突合せ横継手, リブ付荷重非伝達十 字継手のデータを収集整理した。参考文 献，収集方針等の詳細は文献による2)。 完全片振り $R=0$ での $S-N$ 線図を Fig. 1〜6 に示す。

船体のように不規則外力を受けるもの
軟鋼のそれ之比べ疲労限強度では差は少ないが，低繰返 し強度ではより差がある。したがって疲労限を超える応 力を受ける不規則外力下では, 低繰返し強度域で高張力 鋼は疲労強度上軟鋼より高強度であるため, 同じ繰返し に対し低い累積被害度となり，数值的にはわずかである 可能性もあるが，より高強度である。

船体は波浪による不規則外力を受ける構造物であり， 㝿労強度により寸法の定まる部材についてもKファクタ (使用板厚の軟鋼に対する減少率)により, その数值的 根拠があいまいながらも，寸法差をつけている。

不規則外力下の高張力鋼の許容応力比は IIW (国際溶 接会議) 等でも比較的活発に研究されており1), また船 級協会においても疲労強度の考慮を明記したマニュア ル, ルールでは高張力鋼を使用するに当っての疲労強度 上, 寸法決定のための係数が各種示されている。Det NV の “Ships' Load and Strength Manual” (1978) では, 疲労強度は降伏応力 $\sigma_{Y}$ の平方根に依存すると し，高張力鋼のそれの軟鋼との比は $\sqrt{ } \sigma_{Y} / 24$ で表わされ る。 $K$ ファクタは $32 \mathrm{k}$ 級鋼で $0.866,36 \mathrm{k}$ 級鋼で 0.8165 である。German Lloyd's の Vorshriften (1980) によると, 高張力鋼の疲労強度の軟鋼に対する強度比は $1+c^{2} y$ で表わされる。c $y$ は抗張力により与兄られる係数である。Table 1 に強 度比および $K$ ァクタ（強度比の逆数になる）を示す。

GL と NVのKファクタの取扱いを比較すると, 応 力集中率が高いほど高張力鋼と軟鋼の疲労強度差が少な いといら現象をこまかく分けた点で GL の方が合理的で あると思われるが、ルールの使用実績は少なく，実験デ 一タ，実船実績を積み重ね今後数值的に吟味すべき予地 があろう。な的，他の船級協会ルールにおける一般的 $\mathrm{K}$

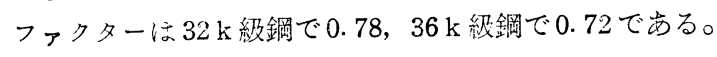

\section{3 累皘被害度からみた高張力鋼係数と $2 \sim 3$ の施工上の問題}

高張力鋼の基礎継手の疲労強度データについては,
は累積被害度をもとに議論すべきとの見解のもとに，前 記した軟鋼および高張力鋼の 3 種の基礎継手について累 積被害度を計算した。計算条件は下記のとおりである。

a) 抗張力は, 軟鋼で $45 \mathrm{~kg} / \mathrm{mm}^{2}$, 高張力鋼で 55 $\mathrm{kg} / \mathrm{mm}^{2}$ とした。 b ) 疲労限以下の強度に対する配慮 として Haibach 法3) を用いた。 c) 応力範囲と累積頻

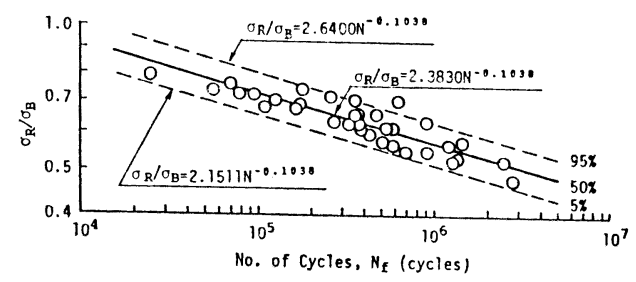

Fig. $1 S-N$ curve of base metal with mill scale (MS)

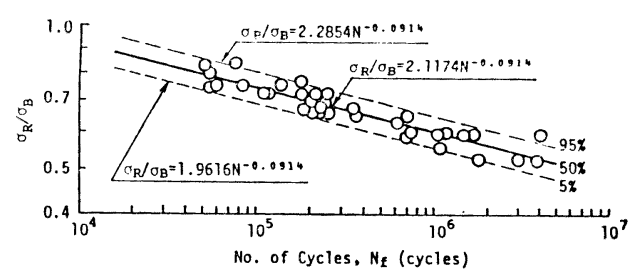

Fig. $2 S-N$ curve of base metal with mill scale (HT 50)

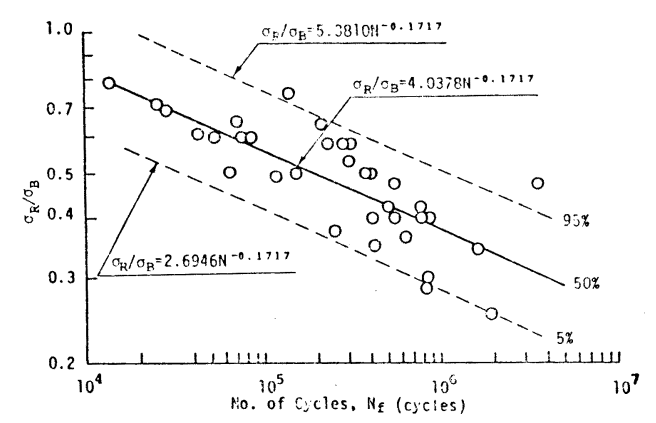

Fig. $3 S-N$ curve of butt welded joint as welded (MS) 


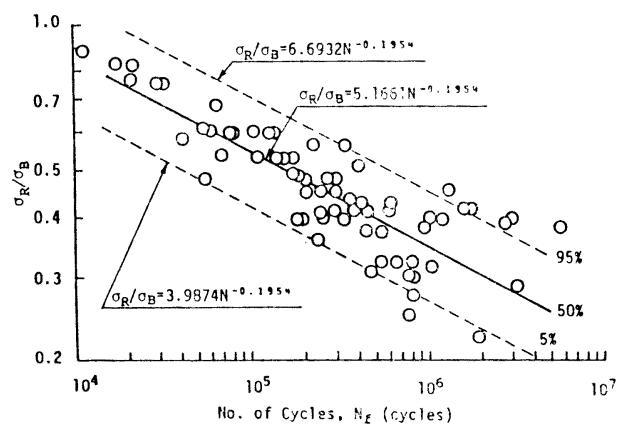

Fig. $4 S-N$ curve of butt welded joint as welded (HT 50)

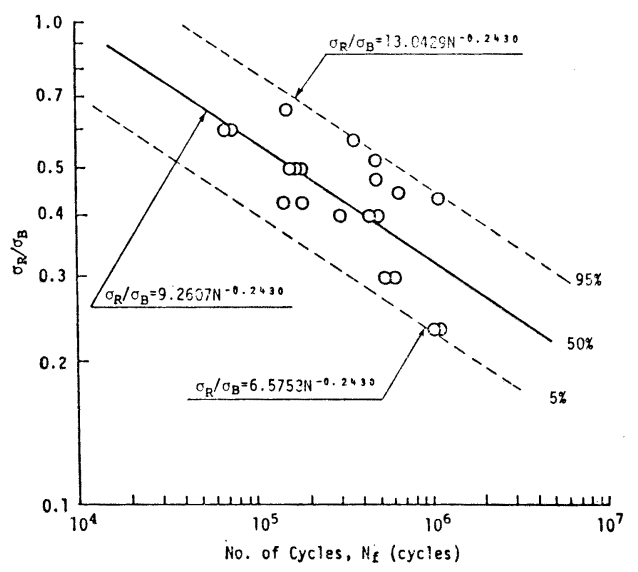

Fig. $5 S-N$ curve of non load carrying type cruciform welded joint (MS)

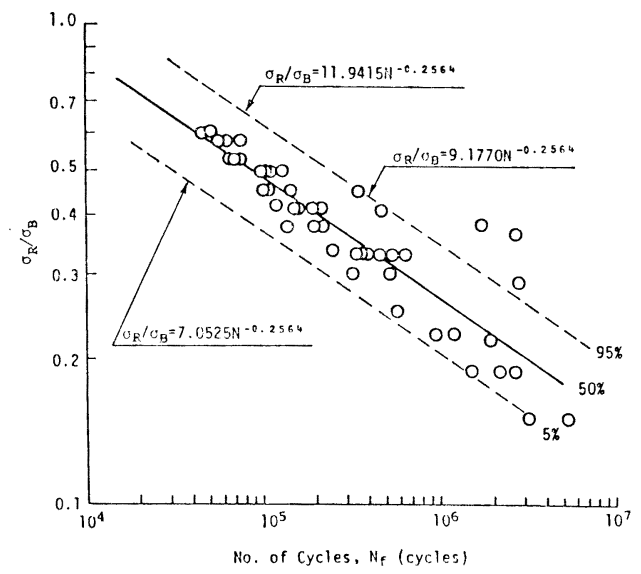

Fig. $6 S-N$ curve of non load carrying type cruciform welded joint (HT 50)

度の関係を片対数グラフ上で直線とした。d）応力繰返 乙数を 20 年 $10^{8}$ 回とした。e ) 平均応力の影響を無視 した。累積被害度の計算結果が 1.0 となる軟鋼と高張力 鋼での応力比を Fig. 7 に示した。この結果は応力集中 の高い継手ほぞ高張力鋼が相対的に低強度であり，GL

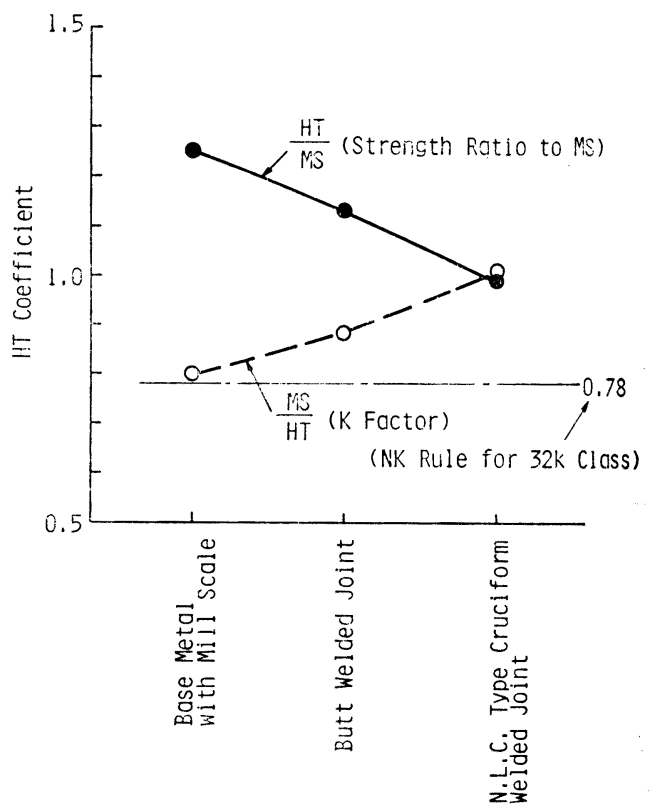

Fig. 7 Coefficient of high tensile steel obtained from cumulative fatigue damage

のルールを裏付ける結果となった。

高張力鋼が切欠に敏感なゆえに，工作法上気にかかる 点がいくつかある。そのうちガス切断について文献をを もとに若干ふれる。

ガス切断の表面粗さについてみれば，黑皮と同程度の 粗度 $60 \mu \mathrm{m}$ 以下ならば疲労強度に与学る粗さの影響は ない。通常の切断であれば $10^{5} \sim 10^{6}$ 回時間強度は引張強 さとともに上昇する（しかし $0.5 \mathrm{~mm}$ 程度もの切断欠 皕があると疲労強度は約 $1 / 2$ になることもありらる)。

\section{4 施工による強度改善法概要}

施工による強度改善法としていくつかの方法が実用化 されている。その主要な，実施法と特徵を飯田教授の論 文 ${ }^{5}$ より拔粋し Table 2 に強度の向上度合と合わせて示 于。

TIG ドレスは, 橋梁, パワーシャベルの疲労強度向 上対策に実用化されており，通常のガス溶接と同じ方法 で行える。強度の向上は 1.5 倍以上は期待できるようで ある。

グラインダードレスは機械的な加工であり, 石油掘削 リグの仕口等に使用されている。古くからの方法であ り，なじみもあり船主, 船級協会に認められやすいが, 施工に要する時間が多い欠点がある。

強度向上用溶接棒は各溶接棒メーカーで閉発されてい るが，強度の向上度合は，いわゆる化粧盛程度でありさ ほど大きなものではない。 
Table 2 Comparison of characteristics of various method improving fatigue strength in welded joint

\begin{tabular}{|c|c|c|c|c|c|c|}
\hline \multirow[b]{2}{*}{ Method } & \multirow[b]{2}{*}{ Type of helded Joint } & \multicolumn{2}{|c|}{ Workability } & \multirow{2}{*}{ Steel } & \multirow{2}{*}{$\begin{array}{l}\text { Fatigue } \\
\text { Strength } \\
\left(2 \times 10^{6}\right) \\
\text { Improving } \\
\text { Ratio }\end{array}$} & \multirow{2}{*}{$\begin{array}{l}\text { IIW XII } \\
\text { Doc. No. }\end{array}$} \\
\hline & & $\begin{array}{l}\text { Shop } \\
\text { Welding }\end{array}$ & $\begin{array}{l}\text { Field } \\
\text { Welding }\end{array}$ & & & \\
\hline \multirow{4}{*}{$\begin{array}{l}\text { TIG } \\
\text { Dressing }\end{array}$} & SAld Butt & \multirow{4}{*}{ Good } & \multirow{4}{*}{$\begin{array}{c}\text { Slightly } \\
\text { Good }\end{array}$} & HT 50 & $\begin{array}{l}2.31 \\
1.56\end{array}$ & \multirow{4}{*}{$\begin{array}{l}735-74 \\
771-75 \\
773-75 \\
774-75 \\
829-77 \\
830-77\end{array}$} \\
\hline & SMAW Butt & & & & 1.5121 .75 & \\
\hline & SHAW Fillet & & & HT 80 & $2.79 n 3.53$ & \\
\hline & MIG Fillet & & & HT 60 & 1.43 & \\
\hline \multirow{5}{*}{$\begin{array}{l}\text { Plasma } \\
\text { Dressing }\end{array}$} & SAw Butt & \multirow{6}{*}{ Good } & \multirow{6}{*}{ Bad } & \multirow{3}{*}{ HT 50} & 1.40 & \multirow{5}{*}{$\begin{array}{l}774-75 \\
829-77\end{array}$} \\
\hline & SMFW Butt & & & & 1.65 & \\
\hline & SMAW Fillet & & & & 3.21 & \\
\hline & SMA.W Butt & & & \multirow{2}{*}{ HT 80} & 1.73 & \\
\hline & SMAW Fillet & & & & 3.57 & \\
\hline $\begin{array}{l}\mathrm{CO}_{2} \text { Soft } \\
\text { Plasma }\end{array}$ & MIG Fillet & & & HT 60 & 1.77 & $830-77$ \\
\hline \multirow{8}{*}{$\begin{array}{l}\text { Improved } \\
\text { Coated } \\
\text { Electrode }\end{array}$} & \multirow{3}{*}{$\begin{array}{l}\text { SMAW } \\
\text { Fillet, Horizontal }\end{array}$} & \multirow{8}{*}{ Good } & \multirow{8}{*}{ Good } & HT 50 & 1.19 & \multirow{3}{*}{$828-77$} \\
\hline & & & & HT 60 & 1.86 & \\
\hline & & & & HT 80 & 1.71 & \\
\hline & $\begin{array}{l}\text { SMAW } \\
\text { Fiilet, Horizontal }\end{array}$ & & & \multirow{3}{*}{ HT \&O } & $1.49 \sim 2.27$ & \multirow{2}{*}{$\begin{array}{l}735-74 \\
772-75 \\
829-77\end{array}$} \\
\hline & $\begin{array}{l}\text { SMAW } \\
\text { Fillet, Horizontal }\end{array}$ & & & & $1.69 n 2.27$ & \\
\hline & $\begin{array}{l}\text { SMAW } \\
\text { Fillet, Vertical Down }\end{array}$ & & & & $1.25 \sim 1.69$ & $835-77$ \\
\hline & $\begin{array}{l}\text { SMAW } \\
\text { Fillet, Horizontal }\end{array}$ & & & \multirow{2}{*}{ HT 30} & $1.22 \sim 1.37$ & \\
\hline & $\begin{array}{l}\text { SMAN } \\
\text { Fillet, Vertical Down }\end{array}$ & & & & $1.25 \sim 1.45$ & \\
\hline \multirow{4}{*}{$\begin{array}{l}\text { Grinder } \\
\text { Dressing }\end{array}$} & SAW Butt & \multirow{4}{*}{ Bad } & \multirow{4}{*}{ Bad } & HT 50 & $1.58 \sim 2.36$ & \multirow{4}{*}{$\begin{array}{l}735-74 \\
774-75 \\
829-77 \\
830-77 \\
835-77\end{array}$} \\
\hline & SA Aiv Butt & & & HT 80 & 1.71 & \\
\hline & \$16 fillet & & & HT 60 & 1.25 & \\
\hline & $\begin{array}{l}\text { SHAw } \\
\text { Fillet, Horizontal }\end{array}$ & & & HT 80 & 1.05 & \\
\hline
\end{tabular}

SAW : Submerged Arc Welding

SMAW : Shield Metal Arc Welding

MIG : Metal Inert Gas Welding

本研究では実績もあり造船所の既存設備で施工可能な TIG ドレスについて検討することにした。

\section{5 二つの付加物を有する隅肉継手の疲労試験}

前述した TIG ドレスによる強度改善効果の確認と疲 労強度上問題となるスティフナ端, スキャロップ部等の 溶接ビード近接部の近接距離の疲労強度に与える影響を 調べる目的で, Fig. 8 に示す二つの付加物を有する邺肉 継手の疲労試験を片振り引張条件下で行った。

供試材は Table 3 に示すとおりであり, 従来型およ
び非水冷型 TMCP 高張力鋼である。試 験系列㤂 Table 4 に示す。

試験結果 (公称応力範囲 $\sigma_{R}$ と破断繰 返し数 $N_{f}$ の関係) を Fig. 9 に示す。 試験結果より，溶接のままの継手の強度 は付加物の近接距離の影響を受け，距離 $18 \mathrm{~mm}$ と $30 \mathrm{~mm}$ はほぼ同じ強度であ るぶ，距離 $40 \mathrm{~mm}$ の継手より若干強度 が低い。TIG 処理をほどこした場合近 接距離 $30 \mathrm{~mm}$ の継手は TMCP 鋼, 従 来鋼之もに同強度であり，2 百万回強度 は溶接のままの継手のほぼ 2 倍に上昇す る。一方, 近接距離 $18 \mathrm{~mm}$ の継手に TIG ドレスをほどこした場合，溶接の ままの継手より強度が低下している。

これらの強度の差異を生ずる原因につ いて調查した。疲労強度に与える影響因 子のらち, 最大のものは応力集中であ る7。また残留応力, 硬度にも影響を受 ける。この 3 点の因子について以下調査 する。

溶接ビードの趾端形状のマクロ写真の 例 (TMCP 鋼) を Fig. 10 に示す。溶 接のまま継手のビード形状は若干オーバ ーラップぎみであるが各継手ともほぼ同 じである。TIG ドレスを行った継手は ビード形状は良くなっているが，付加物 距離 $18 \mathrm{~mm}$ の継手ではビードがラップしている。ビー

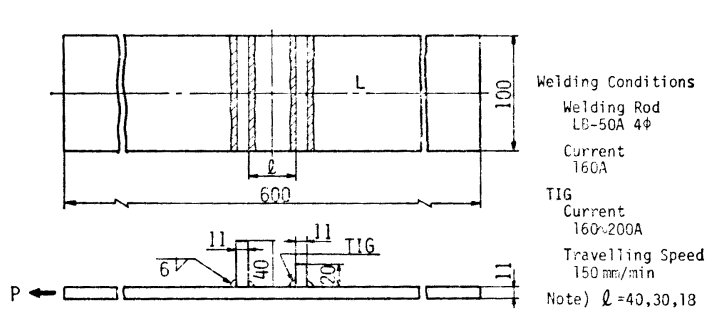

Fig. 8 Specimen for fatigue test

Table 3 Chemical compositions and mechanical properties

\begin{tabular}{|c|c|c|c|c|c|c|c|c|c|c|c|c|c|c|c|}
\hline \multirow[b]{2}{*}{$\begin{array}{l}\text { Produce } \\
\text { Process }\end{array}$} & \multirow[b]{2}{*}{ Material } & \multirow[b]{2}{*}{\begin{tabular}{|} 
Plate \\
Thickriess \\
$(\mathrm{mm})$
\end{tabular}} & \multicolumn{7}{|c|}{ Chemical compositions } & \multicolumn{3}{|c|}{$\times 100(\%)$} & \multicolumn{3}{|c|}{ Mechanical Properties } \\
\hline & & & $c$ & $\mathrm{Si}$ & Mn & $P$ & S & $\mathrm{Cu}$ & $\mathrm{Ni}$ & $\mathrm{Cr}$ & Al & Ceq. & $\begin{array}{l}\text { Yielding } \\
\text { Stress } \\
\left(\mathrm{kgf} / \mathrm{mm}^{2}\right)\end{array}$ & $\begin{array}{l}\text { Tensile } \\
\text { Stress } \\
\left(\mathrm{kgf} / \mathrm{mm}^{2}\right)\end{array}$ & $\begin{array}{c}\text { Elongation } \\
(\%)\end{array}$ \\
\hline $\begin{array}{c}\text { TMCP } \\
\text { (Air } \mathrm{COO} 1)\end{array}$ & & & 12 & 47 & 754 & 1.8 & 0.3 & 23 & 16 & 一 & 2.8 & 40 & 39 & 55 & 24 \\
\hline $\begin{array}{l}\text { Conven } \\
\text {-tional }\end{array}$ & $(R A S Z)$ & & 14 & 43 & 121 & 2.8 & 0.1 & 1 & 2 & 2 & 3.2 & 38 & 35 & 53 & 24 \\
\hline
\end{tabular}

Ceq. $=C+\frac{M n}{6}+\frac{S i}{24}$ 
Table 4 Test series

\begin{tabular}{|c|c|c|c|c|c|c|}
\hline \multirow{2}{*}{ Material } & \multicolumn{2}{|c|}{18} & \multicolumn{2}{|c|}{30} & \multicolumn{2}{|c|}{40} \\
\hline & As -Welded & TIG Dress & As - Welded & TIG Dress & As-Weided & TIG Dress \\
\hline TMCP HT & CR18 & CRTI8 & CR3O & CRT30 & CR4O & - \\
\hline Conventional $\mathrm{HT}$ & HTר8 & - & - & HTT3O & $\mathrm{HT} 4 \mathrm{OO}$ & - \\
\hline
\end{tabular}

ド近接による応力集中の干啮については，趾端の曲率半 式の $2 \sim 3$ 倍以下になると影響が出るとされている ${ }^{6)}$ ビードの趾端の曲率半径は Table 5 より最大 $1.5 \mathrm{~mm}$ であるので, CRT 18 (TIG ドレス付加物距離 $18 \mathrm{~mm}$ ) 以外は応力集中の干涉はないと考劣うる。すた Table 5 は干啮を考党ない応力集中の計算例（ビード形状は型取 りによる)を示すが，TIG ドレスにより応力集中率が 低下することがわかる。

付加物間の残留忍力のスリット法による計測結果を

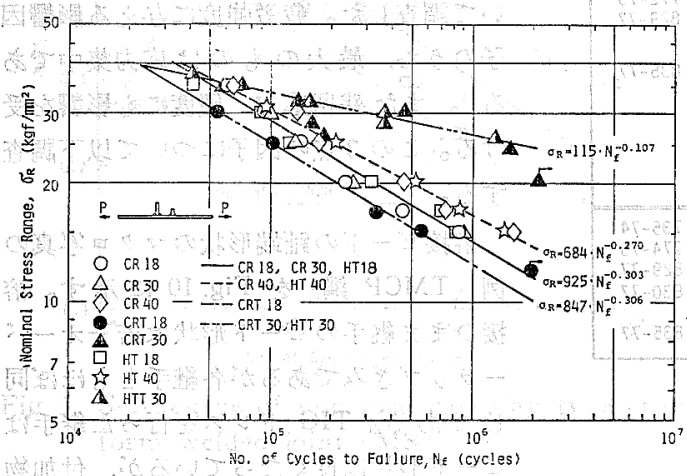

Fig. 9 Fatigue test result of joint with two attachment
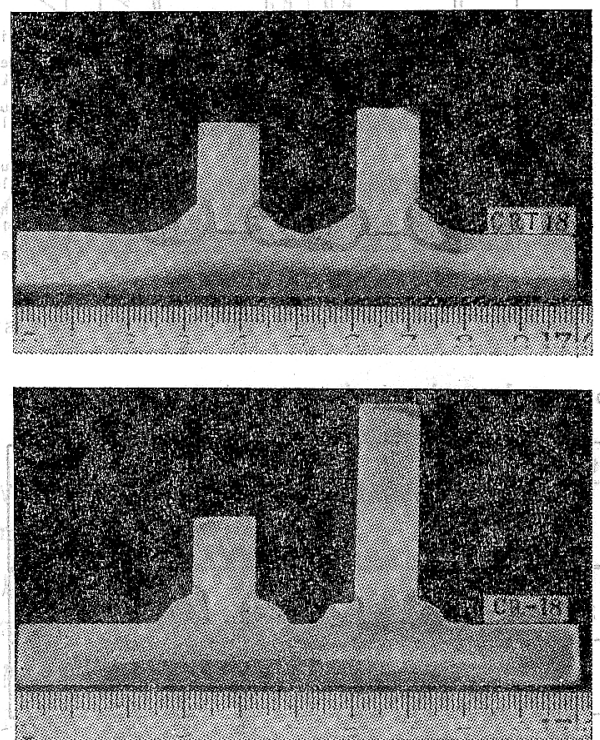

Fig. 11 飞示可。隅肉溶接側の表面より $1.5 \mathrm{~mm}$ 深さラ インに治った残留応力は溶接のままで $5 \sim 10 \mathrm{~kg} / \mathrm{mm}^{2}$ の 值であるが，TIG ドレスにより $30 \sim 40 \mathrm{~kg} / \mathrm{mm}^{2}$ にふえ ることがわかる。

溶接趾端近傍の硬度分布の計測例を Fig. 12 に示す。 Fig. 12 より溶接のままの場合と TIG ドレスを行った 場合顕著な硬度の差は認められない。

以上より，TIG ドレスによる強度低下の主原因とな ららるのはビードの近接と残留応力の增大であることが わかる。二つの原因のうちビードの近接の方が影響が大 きい，これは Fig. 11 に示すよらに高強度を示す CRT 30 でも残留応力が大きいことが根拠である。

\section{6 詳細構造改良}

隅肉溶接部においては, Fig. 7 に示すとおり軟鋼と高 張力鋼に疲労強度差がない為, 高張力鋼使用により相対 的な疲労強度低下が生じる。したがって，施工面での強 度向上対策を行わ机い場合，詳細構造を变更して応力集 中の軽減をはからね棪ならない。

たと壳ばスロット構造に和いては，多くの研究がなざ れているが8)，杂れよりき裂の生じやすいウェブスティ フナ基部についてみれば Table 6 た示すよらな種類があ
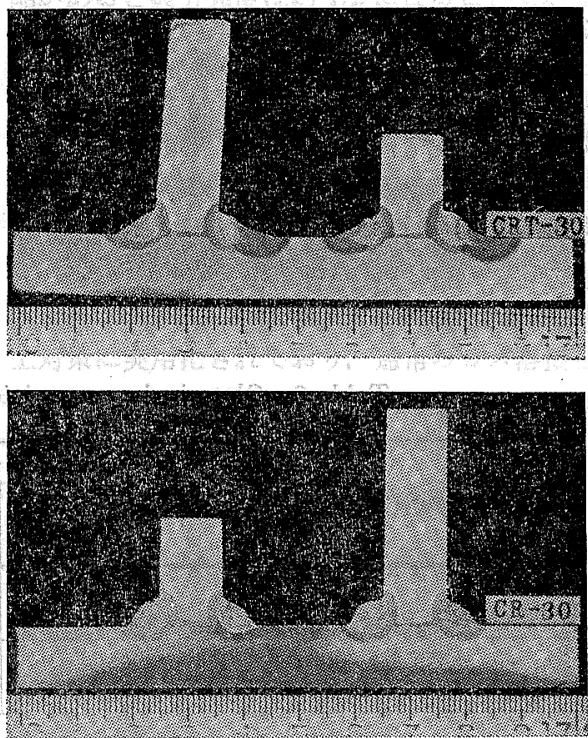

Fig. 10 Macro of specimen 
Table 5 Stress concentration factor at welded toe (sampled value)

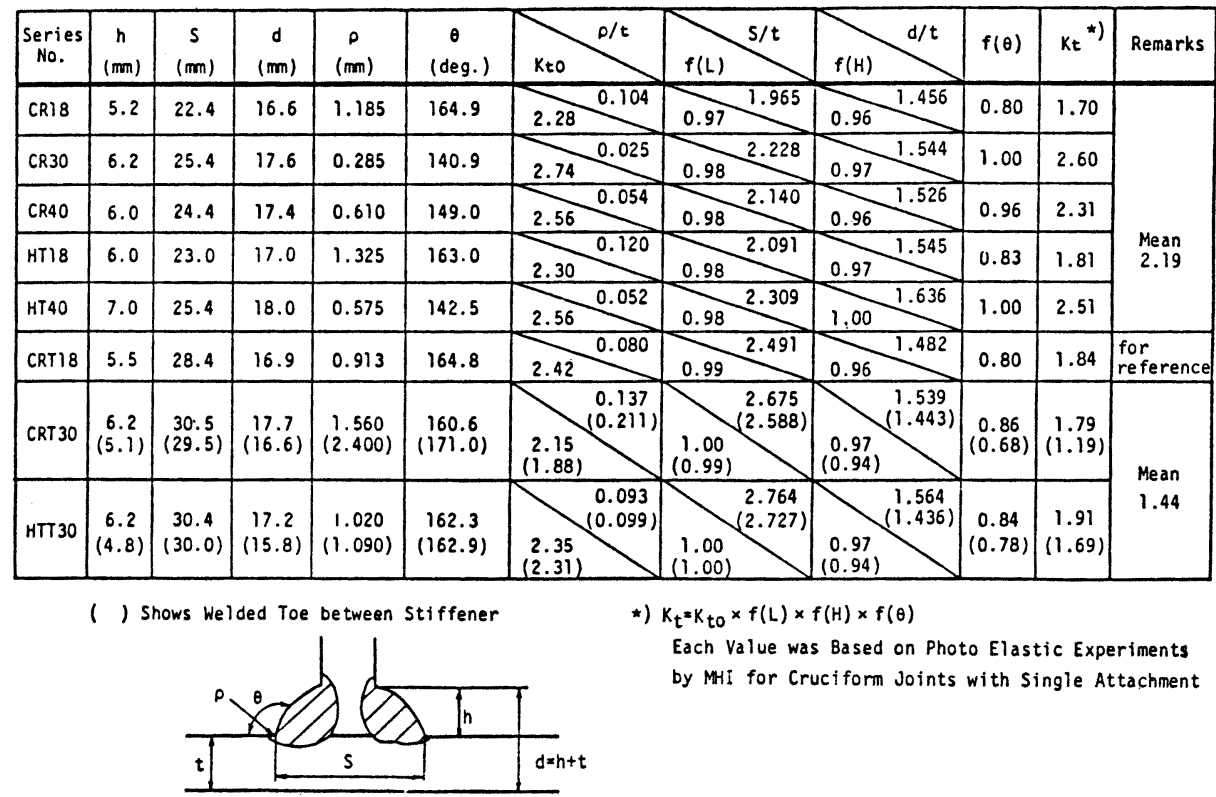

Used Gage

Gage Length $0.2 \mathrm{~mm}$

Gage Factor 1.99
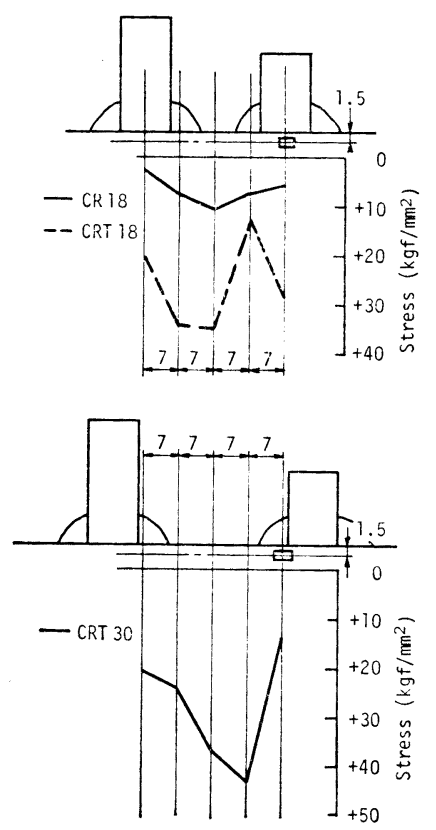

Fig. 11 Measured residual stress
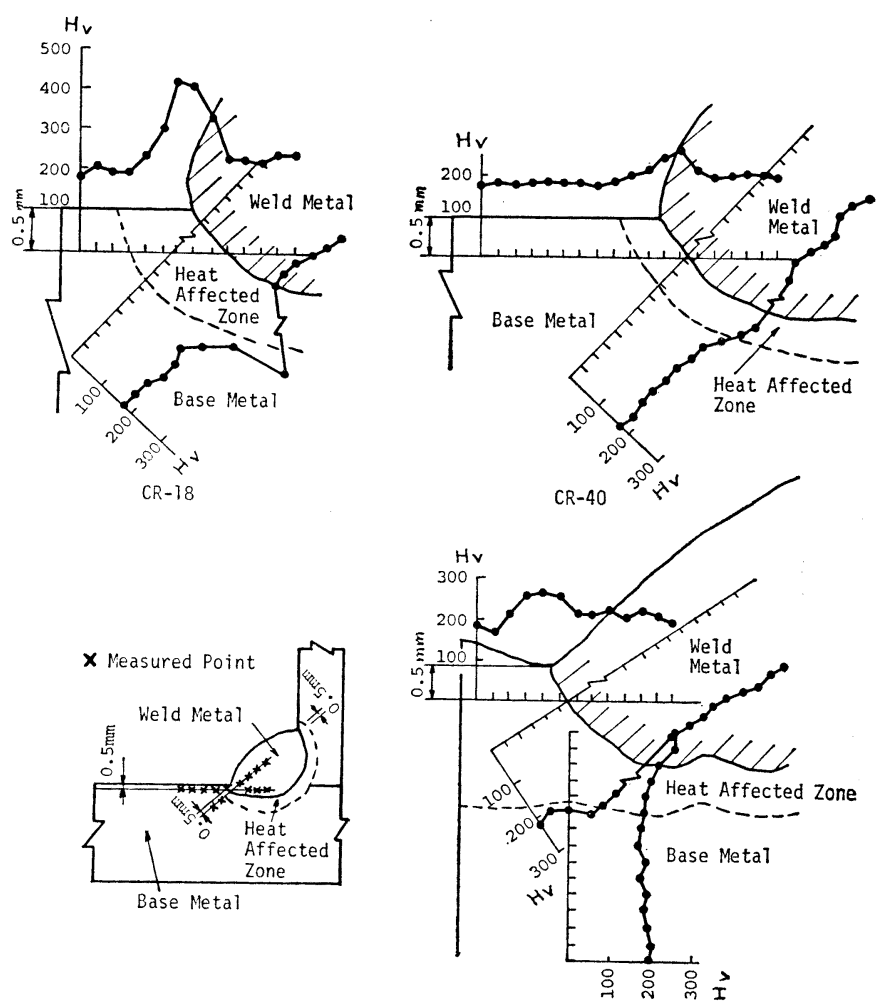

CRT-18

Fig. 12 Distribution of micro Vickers hardness around welded toe 
Table 6 Types of web stiffener root

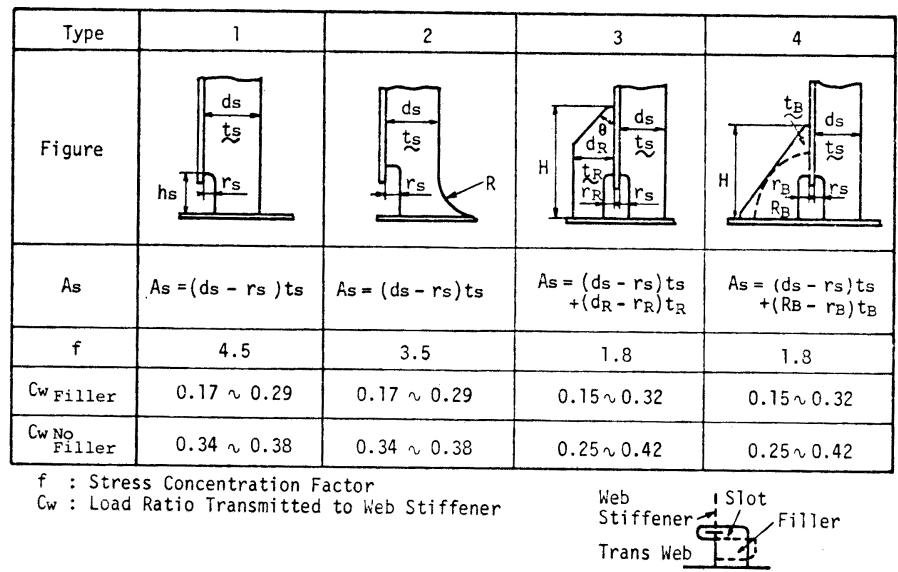

Table 7 Strength increase by figure alternation (sloted part)

\begin{tabular}{|l|l|l|l|l|l|l|l|l|}
\hline & $1 \mathrm{~N}$ & $\mathrm{IF}$ & $2 \mathrm{~N}$ & $2 \mathrm{~F}$ & $3 \mathrm{~N}$ & $3 \mathrm{~F}$ & $4 \mathrm{~N}$ & $4 \mathrm{~F}$ \\
\hline $\mathrm{IN}$ & & & & & & & & \\
\hline $\mathrm{IF}$ & 1.56 & & & & & & & \\
\hline $2 \mathrm{~N}$ & 1.29 & & & & & & & \\
\hline $2 \mathrm{~F}$ & 2.02 & 1.29 & 1.56 & & & & & \\
\hline $3 \mathrm{~N}$ & 3.75 & 2.4 & 2.92 & 1.91 & & & & \\
\hline $3 \mathrm{~F}$ & 5.35 & 3.75 & 4.25 & 2.92 & 1.43 & & & \\
\hline $4 \mathrm{~N}$ & 4.5 & 2.88 & 3.50 & 2.28 & 1.2 & & & \\
\hline $4 \mathrm{~F}$ & 6.41 & 4.5 & 5.10 & 3.50 & 1.72 & 1.2 & 1.43 & \\
\hline
\end{tabular}

$\mathrm{N}:$ No Filler, $\mathrm{F}:$ Filler, $\mathrm{i}:$ Type in Table 6

る。各型式の応力集中, 荷重分担より形状を变えた場合 の強度上昇率を文献 8 ) をもとに求める。Table 7 にそ の結果を示す。表中の数值は強度上昇率であり矢印に形 状を変更したことを示す。船級協会ルールによる $32 \mathrm{k}$ 級高張力鋼の $K$ ファクタは 0.78 (高張力鋼変更にとも なう軟鋼疲労強度に対する強度減少率 1.282 )，36k 級 高張力鋼の $K$ ファクタは 0.72 (強度減少率 1.389）で あるので，たとえば $K$ ファクタで大骨のウェブ等の板厚 を落した場合，軟鋼と同じ疲労強度であるためには， Table 7 中で $32 \mathrm{k}$ 級鋼の場合は 1.28 以上, $36 \mathrm{k}$ 級鋼 の場合は 1.389 以上になるような形状変更が必要とな ろう。もちろんウェブスティフナ基部の面積 $A_{s}$ を落さ ない処置もある。

Fig. 13 に示すような桁端構造についてみると, 応力 集中率は端の角度 $\theta$ や先端の伸しの長さ $b$ に大きく影響 される ${ }^{9,10)}$ 。端部の詳細形状処理による応力集中減少策 としては $\theta, b$ の寸法変更の他, Fig. 13 に示すトウ端 スニップ $(\mathrm{S})$, 面材端のテーパ, サーピン $(\mathrm{T})$, 部分 增厚 (I)，パッド板 $(\mathrm{P})$ 等の採用がある。これらの 形状に対する応力集中率は文献 9),10）に示されてい る。前記したスロットに护けると同様な方法で桁端構造 飞高張力鋼を使用に当って必要な形状变更を求めらる。
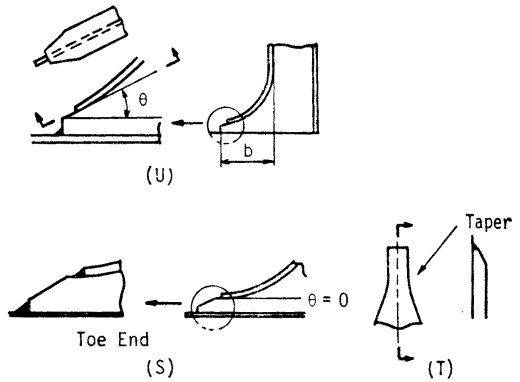

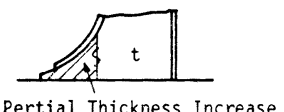

$(=1.6 \mathrm{t})$

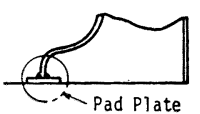

(P)
(I)

Fig. 13 Figure of hold frame end

$$
7 \text { 結 言 }
$$

最近船船の性能向上の必要性々新制御圧延鋼板の開発 により船壳構造への高張力鋼使用率が高まりつつある。 本研究は高張力鋼使用に上る相対的疲労強度低下に対処 するための方法について考察を行った。今後の問題る多 くあるが以下の結論を得た。

（1） 高張力鋼は疲労強度上, 応力集中の大きな継手 ほど軟鋼に比しての相対的強度向上は少ない。

（2）施工による強度改善策としての TIG ドレスを 行う場合、ビード趾端が近接する所には使用できない。

（3）詳細構造改良に上る応力集中率低隇対策は，わ ずかな形状変更, 寸法変更により高張力鋼使用による相 対的疲労強度低下を技ぎないらる。

本研究実施に当り有益な協力, 助言をいただけ SR 200-11 の委員各位抢よび社内関係各位に感謝の意を表 する。 
参考文 献

1) 例えば, Jan Olef Sperle： Fatigue Strength of Welded Joints under Variable Amplitude Loading, IIW-XIII-963-80.

2) 例忩ば, 井上克明, 矢島 浩, 阪井大輔, 他: 新 制御王延型 50 キ口級高張力鋼溶接継手部の疲学 強度とその評価, 西部造船会会報, 第 67 号, 昭 和 59 年 3 月.

3) E. Haibach: The allowable stress under variable amplitude loading of welded joints, Fatigue of Welded Structure Conference, The Welding Institute, 1970.

4) Netherlands Institute of Welding, Working Group 1913: The Properties of Flame Cut Edges, Final Report 1975.

5) K. Iida : Brief Summary of Japanese Docu- ments Concerned with the Improvement of Fatigue Strength of Welded Joints, IIW-XIII862-77.

6）西田正孝: 応力集中, 森北出版.

7) 的場正明：信頼性解析にもとづく船殸構造の疲労 設計, 日本造船学会論文集, 第 151 号, 昭和 57 年.

8) K. Iida, M. Matoba : Japanese Study on the Fatigue Strength of Slotted Parts in Ship's Hull Members, IIW-XIII-834-77.

9) K.Iida, M. Matoba : Evaluation of Fatigue Strength of Hold Frame Ends in Ship Hulls, IIW-XIII-950-80.

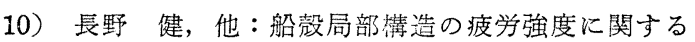
研究 (第 2 報), 石川島播磨抆報 17-5, 昭和 52 年. 